\title{
Five new species of the Genus Carpelimus Leach, 1819 from Thailand and the Philippines (Coleoptera: Staphylinidae: Oxytelinae)
}

\author{
Пять новых видов рода Carpelimus Leach, 1819 из Таиланда \\ и Фихиппин (Coleoptera: Staphylinidae: Oxytelinae)
}

\author{
M.Yu. Gildenkov \\ М.Ю. Гильденков
}

Smolensk State University, Przhevalsky str. 4, Smolensk 214000, Russia. E-mail: mgildenkov@mail.ru
Смоленский государственный университет, ул. Пржевальского, 4, Смоленск 214000, Россия.

KEY WORDS: Coleoptera, Staphylinidae, Carpelimus, new species, Oriental region, Thailand, Philippines.

КЛЮчЕВЫЕ СЛОВА: Coleoptera, Staphylinidae, Carpelimus, новые виды, Восточная биогеографическая область, Таиланд, Филиппины.

ABSTRACT: Five new species of genus Carpelimus are described from the Oriental biogeographic region: Carpelimus (Trogophloeus) notatus sp.n., Carpelimus (Bucephalinus) nothus sp.n., Carpelimus (Trogophloeus) notumus sp.n. and Carpelimus (Trogophloeus) plenus sp.n. from Philippines, Carpelimus (Trogophloeus) vilisus sp.n. from Thailand.

РЕЗЮМЕ: ОПисываются пять новых видов рода Carpelimus из Восточной биогеографической области: Carpelimus (Trogophloeus) notatus sp.n., Carpelimus (Bucephalinus) nothus sp.n., Carpelimus (Trogophloeus) notumus sp.n. и Carpelimus (Trogophloeus) plenus sp.n. из Филиппин, Carpelimus (Trogophloeus) vilisus sp.n. из Таиланда.

\section{Introduction}

This study is a continuation of the previous studies on the genus Carpelimus Leach, 1819 for the Oriental biogeographic region [Gildenkov, 2015; 2018].

This paper is based on the specimens deposited in the following collections: $\mathrm{cMG}$ - private collection of M. Gildenkov (Smolensk, Russia); DUISB Daugavpils University Institute of Systematic Biologi (Latvia); FMNH - Field Museum of Natural History (Chicago, USA); MHNG - Muséum d'Histoire Naturelle, Genève (Switzerland); NHMW - Naturhistorisches Museum Wien (Austria). In the present study, standard methods were used for the taxonomic research of insects; the preparations were made on an MBS-10 binocular microscope. The genital preparations were processed using $10 \% \mathrm{KOH}$ and then fixed in euparal. In the descriptions and diagnoses giving the length to width ratio for the head, pronotum, and elytra, the following standard units were used: 7 standard units $=$ $0.1 \mathrm{~mm}$; thus, 1 standard unit constitutes about 0.0143 $\mathrm{mm}$. Photographs were taken with a Canon EOS 5D Mark III camera and a Canon MP-E $65 \mathrm{~mm}$ objective using the extended focus technology.

Carpelimus (Trogophloeus) notumus Gildenkov, sp.n. Figs 1, 5-7.

MATERIAL. Holotype, $\sigma^{7}$ "PHILIPPINEN-Mindoro $10 \mathrm{~km} \mathrm{~W}$ Puerto Gaiera 24.-25.11.1992, leg. Schillhammer (12)" (NHMW). Paratypes: $10^{27}$ "PHILIPPINEN-Mindoro $10 \mathrm{~km} \mathrm{~W}$ Puerto Gaiera 24-25.11.1992, leg. Schillhammer (12)" (NHMW); 1 우 "PHILIPPINEN: Palawan $20 \mathrm{~km}$ WSW P. Princesa Montible river, 26.3.1994, leg. Zettel, (50a)" (NHMW); $30^{7} 0^{7}, 4$ 우, 2 ex. "PHIL.: Palawan 1994 20km WSW P. Princesa Montible riv., 26.3., leg. Zettel (50a)" (NHMW; 10", 1ㅇ, 1 ex. - cMG); 1 ex. "PHIL.: Palawan 1994 12km S.Brooke's point Cabangaan, Tamlang riv. 1.4., leg. Zettel (55)" (NHMW); 1 ex. "PHIL.: Palawan 1994 9km W P. Princesa Iwahig, 7-8.4., leg. Zettei (60)” (NHMW); 1 우 "Montalba Philippin" "leg Böttcher 1. Los; Staudinger" "Cotypus Trogophloeus philippinus Bernhauer" "Trogophloeus philippinus Brnh" "ex. coll. Scheerpeltz" (NHMW); $20^{7} O^{7}$ "Philippines, Palawan central, along Tarabanan river, NE San Rafael, ca $30 \mathrm{~m}$, 7.XII.1995, Kodada \& Rigova lgt." (MHNG; $10^{7}-\mathrm{cMG}$ ); $10^{7}$ "Philippines, Luzon: Lagunas, Los Banos, vegetation debris near small river, 28.XI.1995, J. Kodada \& B. Rigova lgt.” (MHNG); 1 우 "Philippines, Luzon, Los Banos, small river, 28.XI.1995, J. Kodada \& B. Rigova lgt." (MHNG); $10^{7}$ "Surigao Mindan." "PHILIPPINEN COLL. BOETTCHER DON. STAUDINGER" "Chicago NHMus M. Bernhauer Collection" (FMNH); 1 우 "Montalba Philippin" "PHILIPPINEN COLL. BOETTCHER DON. STAUDINGER" "philippinus Brh. Typ" "Chicago NHMus M.Bernhauer Collection" (FMNH); 1 ㅇ "Montalba Philippin" "Chicago NHMus M.Bernhauer Collection" (FMNH).

DESCRIPTION (holotype). Length $1.9 \mathrm{~mm}$. Colouration brown. Head and abdomen dark brown, pronotum and elytra brown; legs and antennal bases yellow brown, darker

How to cite this article: Gildenkov M.Yu. 2019. Five new species of the Genus Carpelimus Leach, 1819 from Thailand and the Philippines (Coleoptera: Staphylinidae: Oxytelinae) // Russian Entomol. J. Vol.28. No.1. P.30 35. doi: 10.15298/rusentj.28.1.05 
to light brown towards antennal apex. Integument slightly shining, body with short, light-coloured hairs.

Head transverse, with a wide base, ratio of its length (from posterior margin of head to anterior margin of clypeus) to maximum width about 18:25. Neck constriction prominent. Eyes large, convex. Temples well-developed, round, eye diameter in dorsal view about twice as long as temple length. Head about as wide across eyes as across temples (Fig. 1). Head surface with delicate, fine and dense punctation. Diameter of punctures about 3.0 times as small as eye facet. Distances between punctures about equal to their diameter, interspaces smooth, slightly shining. Antennae rather short, antennal segments $1-3$ elongate; segments 4-5 slightly elongate; segments 6-7 about as long as wide; segments 8-10 slightly transverse; segment 11 elongate, conical. Last 3 segments more massive than others and form loose club (Fig. 1).

Pronotum widest about $2 / 3$ its length from base, then narrowed. Lateral margin smoothly rounded (Fig. 1). Ratio of pronotum length to its maximum width about 20:26. Surface of pronotum with delicate, fine and dense punctation; punctation similar to that on head. Pronotal disc with 2 pairs of prominent, symmetrical depressions and 1 unpaired oval depression along midline near apex. Base of pronotal disc with narrow, crescentshaped depressions separated by medial ridge. Central part of disc with rather deep, oval depressions fused across midline to single butterfly-shaped depression (Fig. 1)
Ratio of length of elytra to their combined width about 31:33. Scutellum with shallow, round depressions (Fig. 1). Elytra with rather delicate, fine and dense punctation. Diameter of punctures about 1.5 times as small as eye facet. Distances between punctures slightly smaller than their diameter, interspaces smooth, slightly shining.

Abdomen delicately shagreened.

Aedeagus of characteristic structure (Figs 5-6).

Female. Sexual dimorphism absent, female morphologically similar to male. Spermatheca of characteristic structure (Fig. 7).

COMPARATIVE REMARKS. The new species is somewhat similar to Carpelimus (Trogophloeus) clavulus (Cameron, 1928), being distinguished by a slightly larger body size and a different structure of the aedeagus [Gildenkov, 2015, p. 386, Fig. 20: 1-2]. It is similar and closely related to $C$. vilisus sp.n. and C. plenus sp.n. (see descriptions below), differing slightly from $C$. vilisus sp.n. in having less prominent eyes. It is distinguished from C. plenus sp.n. by a significantly smaller body size and smaller punctation on the body surface and differs markedly in the structure of the aedeagus (Figs 5-6, 10-11).

DISTRIBUTION. Philippines.

ETYMOLOGY. From Latin "notum" (known, familiar); the name alludes to the fact that the description of this species was already considered, for instance, by Max Bernhauer.

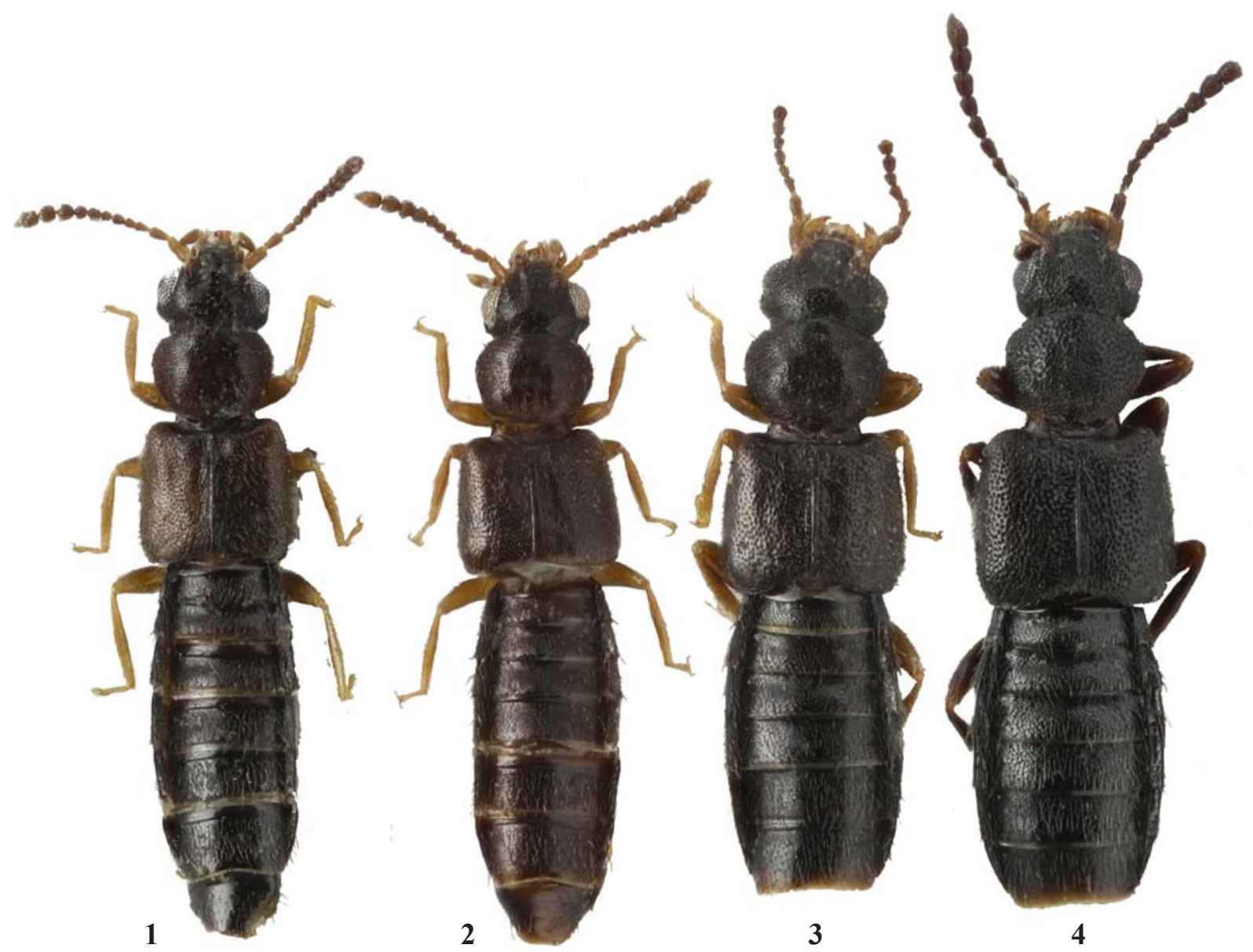

Figs 1-4. Carpelimus (Trogophloeus) spp., holotypes, males, dorsal view: $1-$ C. notumus, sp.n.; $2-$ C. vilisus, sp.n.; $3-$ C. plenus, sp.n.; $4-C$. notatus, sp.n.

Рис. 1-4. Carpelimus (Trogophloeus) spp., голотипы, самцы, сверху: $1-$ C. notumus, sp.n.; $2-$ C. vilisus, sp.n.; $3-$ C. plenus, sp.n.; $4-C$. notatus, sp.n. 
Carpelimus (Trogophloeus) vilisus Gildenkov, sp.n. Figs 2, 8, 9.

MATERIAL. Holotype, ơ "THAILAND: 17./18.11.1995 Phrae Prov., Huai Kaet 50km NE Phrae, leg. Zettel (17b)" (NHMW). Paratype: 1 ㅇ “THAILAND: 16.11.1995 Phrae Prov., Mae Khaem $15 \mathrm{~km}$ E Phrae, ca. 350m, leg. Zettel (16b)" (cMG).

DESCRIPTION (holotype). Length $1.8 \mathrm{~mm}$. Colouration dark brown, legs and antennal bases yellow brown, darker to light brown towards antennal apex. Integument slightly shining, body with short, light-coloured hairs.

Head transverse, with a wide base, ratio of its length (from posterior margin of head to anterior margin of clypeus) to maximum width about 16:24. Neck constriction prominent. Eyes large, convex. Temples well-developed, round, eye diameter in dorsal view about 2.5 times as long as temple length. Head widest across eyes (Fig. 2). Head surface with delicate, fine and dense punctation. Diameter of punctures about 3.0 times as small as eye facet. Distances between punctures about equal to their diameter, interspaces smooth, slightly shining.
Antennae rather short, antennal segments 1-3 elongate; segments 4-7 about as long as wide; segments 8-10 slightly transverse; segment 11 elongate, conical. Last 3 segments more massive than others and form loose club (Fig. 2).

Pronotum widest about $2 / 3$ its length from base, then narrowed. Lateral margin with barely noticeable notch at base, then smoothly rounded (Fig. 2). Ratio of pronotum length to its maximum width about 19:26. Surface of pronotum with delicate, fine and dense punctation; punctation similar to that on head. Pronotal disc with 2 pairs of prominent, symmetrical depressions and 1 unpaired oval depression along midline near apex. Base of pronotal disc with narrow, crescent-shaped depressions separated by medial ridge. Central part of disc with rather deep, oval depressions fused across midline to single butterfly-shaped depression (Fig. 2).

Ratio of length of elytra to their combined width about 30:34. Scutellum with shallow, round depressions (Fig. 2). Elytra with rather delicate, fine and dense punctation. Diameter of punctures about 1.5 times as small as eye facet.
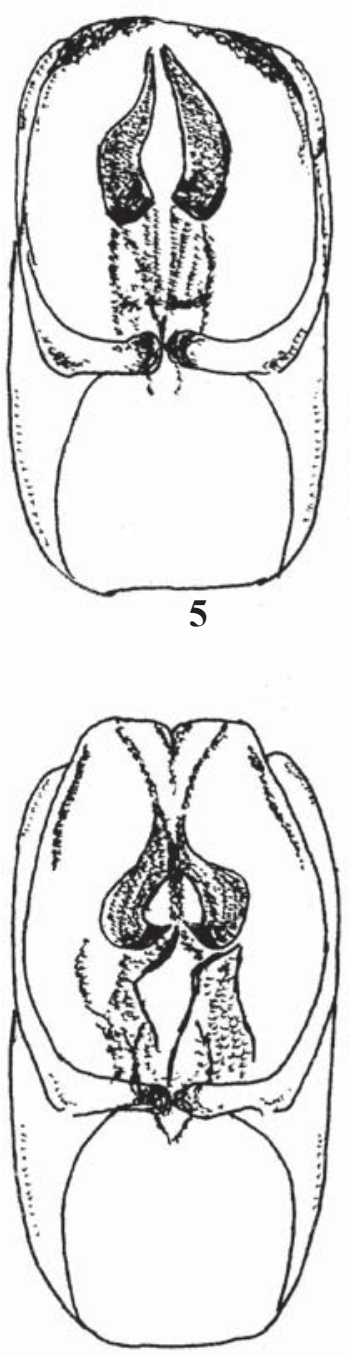

8

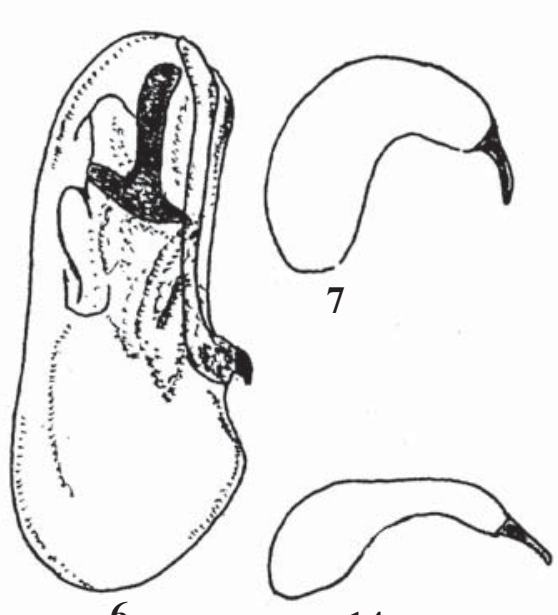

14

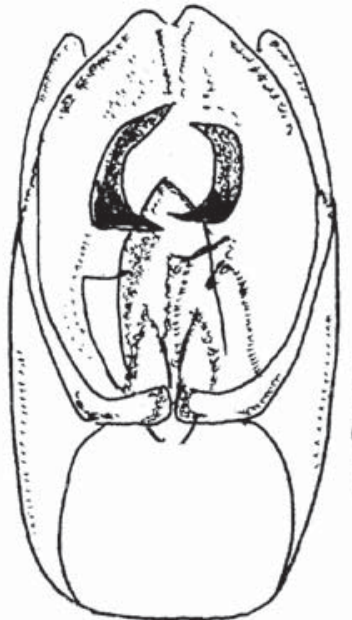

10
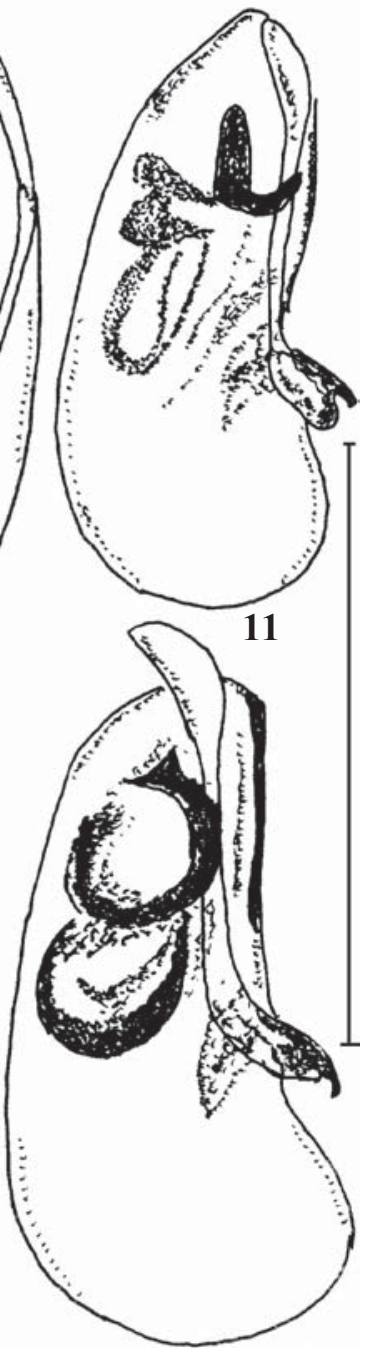

13

Figs 5-14. Genitalia of Carpelimus (Trogophloeus) spp.: 5-7-C. notumus, sp.n.; 8-9 - C. vilisus, sp.n.; 10-11 - C. plenus, sp.n.; 12-14 - C. notatus, sp.n.; 5, 8, 10, 12 - aedeagus, ventral view (holotypes); 6, 9, 11, 13 - aedeagus, lateral view (holotypes); 7, 14 spermatheca (paratypes). Scale bar: $0.25 \mathrm{~mm}$.

Рис. 5-14. Гениталии Carpelimus (Trogophloeus) spp.: 5-7-C. notumus, sp.n.; 8-9 - C. vilisus, sp.n.; 10-11 - C. plenus, sp.n.; 1214 - C. notatus, sp.n.; 5, 8, 10, 12 - эдеагус, снизу (голотипы); 6, 9, 11, 13 - эдеагус, сбоку (голотипы); 7, 14 - сперматека (паратипы). Масштаб: $0.25 \mathrm{~mm}$. 
Distances between punctures slightly smaller than their diameter, interspaces smooth, slightly shining.

Abdomen delicately shagreened.

Aedeagus of characteristic structure (Figs 8-9).

Female. Sexual dimorphism absent, female morphologically similar to male. Spermatheca failed to isolate and its structure is unknown.

COMPARATIVE REMARKS. The new species is similar and closely related to C. notumus sp.n. and C. plenus sp.n. (see descriptions above and below). It differs from $C$. notumus sp.n. in having slightly more prominent eyes and from $C$. plenus sp.n. in having a significantly smaller body size and smaller punctation on the body surface. It differs markedly in the structure of the aedeagus (Figs 5-6, 8-11).

DISTRIBUTION. Thailand.

ETYMOLOGY. From Latin "vilis" (worthless, insignificant) referring to a small difference in its external appearance from $C$. notumus.

\section{Carpelimus (Trogophloeus) plenus Gildenkov, sp.n.} Figs 3, 10-11.

MATERIAL. Holotype, O "Philippines, Luzon: Lagunas, Los Banos, vegetation debris near small river, 28.XI.1995, J. Kodada \& B. Rigova lgt." (MHNG). Paratypes: 1 \% "Philippines, Luzon: Lagunas, Los Banos, vegetation debris near small river, 28.XI.1995, J. Kodada \& B. Rigova lgt." (MHNG); $10^{7}$ (teneral) "Philippines, Luzon, Los Banos, small river, 28.XI.1995, J. Kodada \& B. Rigova lgt." (cMG).

DESCRIPTION (holotype). Length $2.0 \mathrm{~mm}$. Colouration dark brown, legs and antennae light brown. Integument slightly shining, body with short, light-coloured hairs.

Head transverse, with a wide base, ratio of its length (from posterior margin of head to anterior margin of clypeus) to maximum width about 19:28. Neck constriction prominent. Eyes large, convex. Temples well-developed, round, eye dimeter in dorsal view markedly longer than temple length, but less than 1.5 times as long as temple length. Head about as wide across eyes as across temples (Fig. 3). Head surface with delicate, fine and dense punctation. Diameter of punctures about 2.5 times as small as eye facet. Distances between punctures about equal to their diameter, interspaces smooth, slightly shining. Antennae rather short (Fig. 3), antennal segments 1-3 elongate; segments $4-5$ and 7 slightly elongate; segments 6 and $8-10$ about as long as wide; segment 11 elongate, conical (structure of segments 9-11 from male paratype). Last 3 segments more massive than others and form loose club.

Pronotum widest about $2 / 3$ its length from base, then narrowed. Lateral margin smoothly rounded (Fig. 3). Ratio of pronotum length to its maximum width about 23:31. Surface of pronotum with delicate, fine and dense punctation; punctation similar to that on head. Pronotal disc with 2 pairs of prominent, symmetrical depression and 1 unpaired oval depression along midline near apex. Base of pronotal disc with narrow, crescent-shaped depressions barely separated by medial ridge. Central part of disc with rather deep, oval depressions fused across midline to single butterfly-shaped depression (Fig. 3).

Ratio of length of elytra to their combined width about 35:39. Scutellum with shallow, round depressions (Fig. 3). Elytra with rather delicate, fine and dense punctation. Diameter of punctures about equal to that of eye facet. Distances between punctures significantly smaller than their diameter, interspaces smooth, slightly shining.

Abdomen delicately shagreened.

Aedeagus of characteristic structure (Figs 10-11).
Female. Sexual dimorphism absent, female morphologically similar to male. Spermatheca failed to isolate and its structure is unknown.

COMPARATIVE REMARKS. The new species is similar and closely related to $C$. notumus sp.n. and $C$. vilisus sp.n. (see descriptions above). It differs from both species in having a significantly larger body size and a larger punctation on the body surface and can be clearly distinguished by the structure of the aedeagus (Figs 5-6, 8-11).

DISTRIBUTION. Philippines.

ETYMOLOGY. From Latin "plenus" (full, dense) referring to a relatively large body size.

\section{Carpelimus (Trogophloeus) notatus Gildenkov, sp.n.} Figs 4, 12-14.

MATERIAL. Holotype, $O^{T}$ "Philippines, Palawan central, along Tarabanan river, NE San Rafael, ca 30 m, 7.XII.1995, Kodada \& Rigova lgt." (MHNG). Paratypes: $30^{7} \sigma^{7}, 2$ ex. "Philippines, Palawan central, along Tarabanan river, NE San Rafael, ca $30 \mathrm{~m}$, 7.XII.1995, Kodada \& Rigova lgt." (MHNG; $10^{7}-\mathrm{cMG}$ ); $20^{7} 0^{7}$, 2우, 6 ex. "Philippines, Luzon: Lagunas, Los Banos, vegetation debris near small river, 28.XI.1995, J. Kodada \& B. Rigova lgt." (MHNG; 10', 1ex. - cMG).

DESCRIPTION (holotype). Length $2.1 \mathrm{~mm}$. Colouration black, legs and antennae dark brown. Integument slightly shining, body with short, light-coloured hairs.

Head transverse, with a wide base, ratio of its length (from posterior margin of head to anterior margin of clypeus) to maximum width about 19:28. Neck constriction prominent. Eyes large, convex. Temples well-developed, round, eye diameter in dorsal view about 1.5 times as long as temple length. Head widest across eyes (Fig. 4). Head surface with distinct, rather large and dense punctation. Many punctures, especially on vertex, umbilicate, their diameter about equal to that of eye facet. Distances between punctures significantly smaller than puncture diameter, interspaces smooth, slightly shining. Punctures on frons and near antennal insertions much smaller, their diameter more than twice as small as eye facet. Punctures near antennal insertions often fuse into coarsely shagreened surface. Antennae rather long, segments 1-7 very elongate; segments $8-10$ slightly elongate; segment 11 elongate, conical (Fig. 4)

Pronotum widest about $2 / 3$ its length from base, then narrowed. Lateral margin smoothly rounded (Fig. 4). Ratio of pronotum length to its maximum width about 23:30. Surface of pronotum with distinct, rather large and dense punctation. Punctation very similar to that on head. Punctures umbilicate, their diameter about equal to that of eye facet. Distances between punctures significantly smaller than puncture diameter, some punctures fused, interspaces smooth, slightly shining. Pronotal disc with 2 pairs of rather prominent, symmetrical depressions and 1 unpaired shallow oval depression along midline near apex. Base of pronotal disc with narrow, crescent-shaped depressions fused to single horseshoe-shaped depression. Central part of disc with longitudinal, oval depressions (Fig. 4).

Ratio of length of elytra to their combined width about 39:43. Scutellum with shallow, round depressions (Fig. 4). Elytra with distinct, rather large and dense punctation. Punctures simple, their diameter about equal to that of eye facet. Distances between punctures significantly smaller than their diameter, interspaces smooth, slightly shining (Fig. 4).

Abdomen delicately shagreened.

Aedeagus of characteristic structure (Figs 12-13).

Female. Sexual dimorphism absent, female morphologically similar to male. Spermatheca of characteristic structure (Fig. 14). 
COMPARATIVE REMARKS. The new species is similar in umbilicate punctation of the head and pronotum to the representatives of the subgenus Bucephalinus Koch, 1934, but the structure of the aedeagus of this species is unusual for Bucephalinus [Gildenkov, 2015]. It is somewhat similar to a well-known palaearctic species Carpelimus (s. str.) lindrothi (Palm, 1943), differing in its umbilicate punctation of the head and pronotum, well-developed temples and the structure of the aedeagus.

DISTRIBUTION. Philippines.

ETYMOLOGY. From Latin "notatus" (pronounced) referring to a characteristic microsculpture of the body surface.

\section{Carpelimus (Bucephalinus) nothus Gildenkov, sp.n.} Figs 15-17.

MATERIAL. Holotype, $\sigma^{7}$ "Philippines, Mindanao Mount Hamiguitan Range Wildlife Sanctuary, $6^{\circ} 73^{\prime} \mathrm{N} 126^{\circ} 14^{\prime} \mathrm{E}$, about $500 \mathrm{~m}$, 30.III.-2.IV.2018. A. Shavrin leg.” (DUISB). Paratypes: $20^{7} \sigma^{\top}, 1+2,2$ ex. "Philippines, Mindanao Mount Hamiguitan Range Wildlife Sanctuary, $6^{\circ} 73^{\prime} \mathrm{N} 126^{\circ} 14^{\prime} \mathrm{E}$, about $500 \mathrm{~m}$, 30.III.-2.IV.2018. A. Shavrin leg." (DUISB; $10^{7}-\mathrm{cMG} ; 1$ ex. - NHMW); 3 ex. "PHILIPPINES Mindanao Isl., Davao Oriental Prov., Mt. Hamiguitan Range Wildlife Sanctuary, Banakon Creek, narrow valley of small river. $6^{\circ} 74^{\prime} \mathrm{N}$ $126^{\circ} 15^{\prime} \mathrm{E}$, about $400 \mathrm{~m}$ a.s.1. 22-24.03.2018. A. Shavrin $\mathrm{O}^{7} 2^{\prime \prime}$ (DUISB); $10^{7}$ "PHILIPPINES: Mindanao Isl., Davao Oriental Prov., Sitio Bitaugan, Kawa-kawa Riever. $6^{\circ} 46^{\prime} 30.96^{\prime \prime} \mathrm{N} 126^{\circ} 08^{\prime} 41.10^{\prime \prime}$ E. 300 $m$ a.s.1. 24-26.03.2018. A. Shavrin leg. O'4" (cMG).

DESCRIPTION (holotype). Length $1.6 \mathrm{~mm}$. Colouration brown, legs and antennae yellow brown, antennal segments 1-3 and 11 slightly lighter than others. Integument slightly shining, body with short, light-coloured hairs.

Head transverse, with a wide base, ratio of its length (from posterior margin of head to anterior margin of clypeus) to maximum width about 16:23. Neck constriction prominent. Eyes small, slightly convex. Temples well-developed, round, eye diameter in dorsal view much shorter than temple length. Head widest across temples (Fig. 15). Head surface with delicate, fine and dense punctation. Diameter of punctures about 4.0 times as small as eye facet. Distances between punctures about equal to their diameter, interspaces smooth, slightly shining. Antennae rather long, segments 1-3 elongate; segment 5 slightly elongate; segments 4 and 6-10 about as long as wide; segment 11 elongate, conical. Last 3 segments more massive than others and form loose club (Fig. 15).

Pronotum widest about $2 / 3$ its length from base, then narrowed. Lateral margin smoothly rounded (Fig. 15). Ratio of pronotum length to its maximum width about 17:25. Surface of pronotum with delicate, fine and dense punctation; punctation similar to that on head. Punctures distinctly visible. Pronotal disc with 2 prominent depressions along midline: horseshoe-shaped depression near base and rectangular depression in middle part fused with depression at base such that medial ridge forms rounded protrusion (Fig. 15); disc apex with small, oval depression along midline (Fig. 15).

Ratio of length of elytra to their combined width about 26:30. Scutellum with shallow, round depressions (Fig. 1). Elytra with delicate, fine and dense punctation; punctures shallow. Diameter of punctures about twice as small as eye facet. Distances between punctures about equal to their diameter, interspaces smooth, slightly shining.

Abdomen delicately shagreened.

Aedeagus of characteristic structure (Figs 16).

Female. Sexual dimorphism absent, female morphologically similar to male. Spermatheca of characteristic structure (Fig. 17).

COMPARATIVE REMARKS. This species belongs to the "silvestris" species group [Gildenkov, 2014a, b, 2015] together with $C$. silvestris (Cameron, 1918), C. formosae (Cameron, 1940), C. kathmanduensis Herman, 2001, C. haraldi Gildenkov, 2014, C. postremus Gildenkov, 2014, C. snookus Gildenkov, 2014, and C. pseudosilvestris Gildenkov, 2014). It can be clearly distinguished (Figs 16-17) only by the structure of the aedeagus and differs from some of the aforementioned species in the structure of the spermatheca [Gildenkov, 2015, p. 377, Figs 11: 7-13; p. 378, Figs 12: 1-6]. It

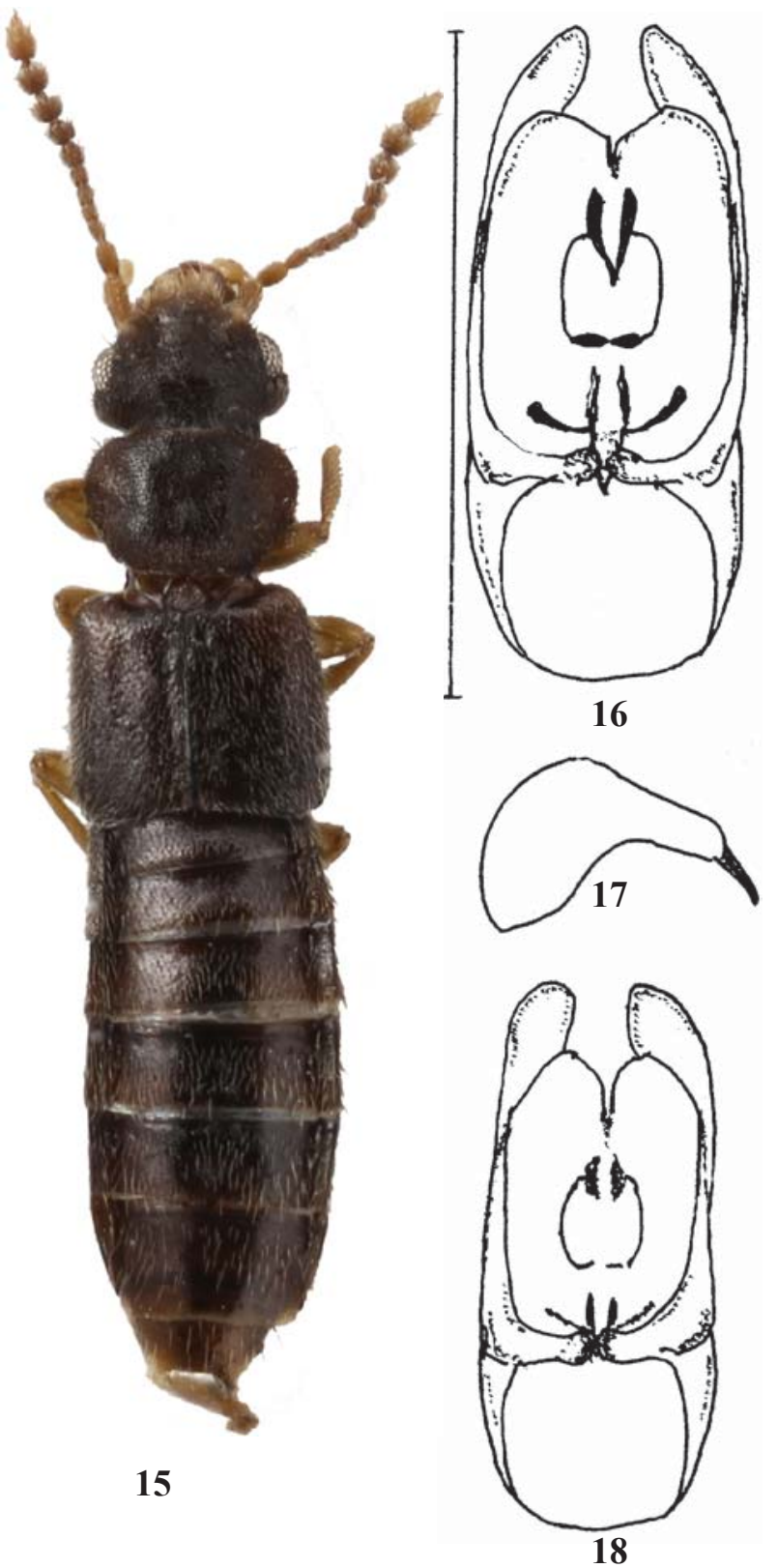

Figs 15-18. Carpelimus (Bucephalinus) spp.: 15-17-C. nothus, sp.n., (15-16 - holotype, male; 17 - paratype, female); 18 - C. postremus Gildenkov, 2014, holotype, male; 15 - habitus, dorsal view; 16,18 - aedeagus, ventral view; 17 - spermatheca. Scale bar (Figs 16-18): $0.25 \mathrm{~mm}$.

Рис. 15-18. Carpelimus (Bucephalinus) spp.: 15-17-C. nothus, sp.n., (15-16 - голотип, самец; 17 - паратип, самка); 18 - C. postremus Gildenkov, 2014, голотип, самец; $15-$ внешний вид, сверху; 16, 18 - эдеагус, снизу; 17 - сперматека. Масштаб (Рис. 16-18): $0.25 \mathrm{~mm}$. 
is most similar in body size and the structure of the aedeagus to a closely related and cohabiting species $C$. postremus. It can be distinguished by its significantly larger body size, darker colouration and the details of the structure of the aedeagus (Figs 16, 18). It is similar to C. pseudosilvestris in the shape of the depressions on the pronotal disc [Gildenkov, 2014b, p. 237, fig. 2].

DISTRIBUTION. Philippines.

ETYMOLOGY. From Latin "nothus" (spurious) referring to a close affinity to $C$. postremus.

Acknowledgements. The author wishes to thank all colleagues for making material available for study: Alexey Shavrin (DUISB); Alfred Newton, Margaret Thayer and James Boone (FMNH); Giulio Cuccodoro (MHNG); Harald Schillhammer (NHMW). I also thank Kirill Makarov for taking the photographs (Moscow Pedagogical State University, Russia).

\section{References}

Gildenkov M.Yu. 2014a (2013). [New species of the genus Carpelimus Leach, 1819 from the "silvestris" and "taprobanae" species groups (Coleoptera, Staphylinidae, Oxytelinae)] // Izvestiya Smolenskogo Gosudarstvennogo Universiteta. No.4(24). P.292305 [in Russian, with English summary].

Gildenkov M.Yu. 2014b. [Five new species of the genus Carpelimus Leach, 1819 from the Oriental Region and Palaearctic (Coleoptera, Staphylinidae, Oxytelinae)] // Izvestiya Smolenskogo Gosudarstvennogo Universiteta. No.2(26). P.232-244 [in Russian, with English summary].

Gildenkov, M.Yu. 2015. [Fauna of Carpelimus of the Old World (Coleoptera: Staphylinidae)]. Smolensk: SmolSU. 414 pp. [In Russian, with English summary]

Gildenkov M.Yu. 2018. Five new species of the genus Carpelimus Leach, 1819, from the Oriental region (Coleoptera: Staphylinidae: Oxytelinae) // Russian Entomological Journal. Vol.27. No.2. P.135-142. 